\title{
SIMULATOR EKSEKUSI INSTRUKSI PADA SISTEM KOMPUTER VIRTUAL
}

\author{
Soetrisno \\ Teknik Informatika,Universitas Pelita Harapan \\ sutrisno.fik@uph.edu
}

\begin{abstract}
ABSTRAK
Sistem komputer modern saat ini semakin canggih dan mudah digunakan karena kompleksitas perangkat keras, dan piranti lunak, semakin tersembunyi dari pengguna. Sehingga, untuk memahami bagaimana sebuah komputer melakukan eksekusi instruksi yang dilakukan oleh mikroprosesor tidak secara mudah dilakukan. Salah satu solusinya adalah dalam bentuk piranti lunak simulator, atau emulator, suatu mikroprosesor tertentu. Penulis merancang dan membuat piranti lunak sistem komputer virtual, terdiri dari mikroprosesor virtual, dan memori virtual. Mikroprosesor virtual dirancang dan dibuat mulai dari rancangan instruction set, dengan format ukuran instruksi yang seragam 32 bits, menyediakan 16 register berukuran 32 bits. Memori virtual yang dibuat pada simulator sebesar 32 kilo bytes. Sistem komputer yang dibuat memungkinkan lebih dari satu program berada di memori, dan mikroprosesor dapat menjalankan program-program yang ada di memori tersebut, meskipun masih dieksekusi secara sekuensial. Satu program dikerjakan hingga selesai, dilanjutkan program berikutnya. Dalam simulator ini, program dapat ditulis menggunakan bahasa mesin berdasarkan rancangan instruction set yang ada, atau program ditulis berupa pseudocode yang akan dikompilasi oleh piranti lunak compiler yang telah dibuat. Menggunakan compiler ini dapat diperlihatkan hasil translasi dari pseudocode ke kode dalam bahasa assembly, juga dalam bahasa mesin, dan serta status register, maupun memori, dari tiap instruksi yang dieksekusi.
\end{abstract}

Keyword : mikroprosesor, instruction set, compiler, sistem komputer, komputer virtual

\section{PENDAHULUAN}

Komputer modern saat ini seperti desktop, laptop, hingga gawai (gadget), semakin canggih dan mudah digunakan, dan diupayakan handal (reliable). Upaya menjadikan sebuah komputer handal, dan implikasinya adalah pemakai dihindarkan dari kerumitan akses ke perangkat keras secara langsung, dan pada tingkatan tertentu juga pada pirani lunak juga, misalnya pada sistem operasi. Kemudahan pemakaian dan penghindaran kerumitan pada kompleksitas perangkat keras, maupun piranti lunak, sangat membantu pemakai untuk fokus pada apa piranti lunak aplikasi yang dibutuhkannya.

Pemakai komputer dalam hal hususnya akses ke perangkat keras, seperti prosesor, semakin tidak mudah dilakukan. Pertimbangannya karena untuk menjamin kehandalan, maka perlu ada perlindungan dengan pelapisan proteksi (shield) dari kemungkinan terganggunya sistem karena akses yang tidak tepat. Salah satu contoh, meskipun pada sistem operasi Windows, masih disediakan akses ke prosesor melalui utility "Debug" yang diakses melalui command line, namun hanya diberikan akses terbatas. Pemanggilan Interrupt tertentu sudah tidak dapat dilakukan, karena diproteksi.

Hal ini menjadi kendala khsususnya untuk keperluan mendukung proses belajar mengajar, seperti pada mata kuliah Sistem Operasi ataupun mata kuliah Organisasi dan Arsitektur Komputer. Pada dua mata kuliah tersebut, masih diperlukan untuk mengenalkan beberapa hal mengenai perangkat keras khususnya prosesor. Beberapa hal tersebut diantaranya register, program counter, addressing, big dan little endian data. Pada program studi tertentu, topik-topik ini tidak menjadi kendala, tetapi pada program studi lainnya, dapat dikatakan sesuatu yang asing.

Simulator, atau emulator, merupakan suatu jalan keluar, akses ke perangkat keras dalam benuk piranti lunak. Sejumlah simulator, dan emulator, telah banyak dibuat, bahkan tidak saja pada tingkatan mikroprosesor, bahkan hingga ke sistem operasi. Simulator mikroprosesor salah satu diantaranya adalah SPIM yang dikembangkan untuk mensimulasikan prosesor MIPS, seperti yang dibahas pada bukunya Patterson dan Hennessy [1]. Emulator untuk prosesor Intel, khususnya prosesor 8086 cukup banyak tersedia di internet.

Secara umum, pada emulator 8086, memungkinkan kita memelajari mikroprosesor dan akses ke prosesor 8086 , dengan membuat program assembly. Kita dapat memelajari di antaranya akses sejumlah interrupt, register, dan lainnya. Emulator ini sangat menarik, dan bermanfaat dalam mendukung proses belajar.

Penulis mengembangkan simulator komputer virtual terdiri dari mikroprosesor virtual, dan memori virtual. Istilah "virtual" yang dimaksudkan penulis adalah bukan akses ke sumber daya perangkat keras mikroprosesor (yaitu Intel prosesor, AMD, dan lainnya), ataupun riil perangkat keras memori (RAM, DDR3, atau DDR4). Komputer virtual yaitu sebuah komputer dalam bentuk piranti lunak yang mana program (dalam bentuk machine code) akan dieksekusi di atas prosesor virtual, dan memanfaatkan memori virtual juga. Pemakai berinteraksi ke komputer virtual ini. Komputer virtual dikembangkan menggunakan bahasa pemrograman Java.

Copyright (c) 2019 Jurnal Mnemonic 
Tujuan dibuatnya komputer virtual ini, untuk membantu mahasiswa dalam proses belajar mata kuliah yang telah disebutkan di atas. Khususnya yang ingin dicapai adalah membantu mahasiswa untuk memahami bagaimana suatu mikroprosesor mengeksekusi instruksi berdasarkan machine code, dan memahami konversi atau translasi perintah bahasa assembly ke machine code. Oleh karenanya, pada simulator yang dibuat, mikroprosesor virtual perlu dirancang himpunan atau kumpulan instruksi (instruction set) yang sederhana diharapkan mudah dipahami, sehingga mendapatkan esensinya.

Sebagaimana diketahui ada dua pola rancangan instruksi yaitu CISC (Complex Instruction Set Code), dan RISC (Reduced Instruction Set Code). Prosesor Intel dirancang menggunakan pendekatan CISC [2][3]. Pada CISC salah satu cirinya adalah ukuran panjang instruksi bervariasi. Sedangkan pada RISC biasanya menggunakan ukuran panjang instruksi yang seragam atau sama, seperti pada prosesor MIPS [1]. Untuk keperluan mendukung tujuan penelitian yang dilakukan, maka mikroprosesor yang dibuat menggunakan ukuran yang sama untuk setiap instruksinya yaitu 32 bits (4 bytes).

Setiap instruksi yang berukuran 32 bits tersebut, dibagi ke beberapa fields, tergantung operasi apa yang diterapkan padanya. Satu field yang pasti ada adalah kode operasi (operation code, atau disingkat opcode) sepanjang 8 bits. Penamaan operasi berupa mnemonic yang dapat digunakan unuk menuliskan kode assembly. Penamaan instruksi terinspirasi dan mengadopsi penamaan pada prosesor Intel dan MIPS [1][2][3].

Himpunan instruksi yang disediakan, dirancang sedikitnya dapat merepresentasikan elemen instruksi dasar dari suatu pemrogram, yaitu sekuens, pencabangan, repetisi menggunakan pencabangan, operasi aritmatika, akses data ke dan dari register dan memori, operasi dasar stack yaitu push dan pop, pemanggilan modul, meskipun ini sesungguhnya dapat dilakukan menggunakan kombinasi conditional dan unconditional jump.

Himpunan instruksi (instruction set) yang dirancang diimplementasi menjadi mikroprosesor virtual. Program sederhana yang meliputi elemen instruksi: sekuens, selection, repetition, memungkinkan dilakukan. Dengan penataan penulisan program dalam bentuk machine code yang benar, dimungkinkan akses data dalam bentuk array dapat pula dilakukan, sebagaimana diketahui array merupakan koleksi data di memori. Mikroprosesor yang dibuat masih merupakan mikroprosesor integer, yaitu hanya dapat mengolah data numerik integer.

Semua fasilitas operasi yang disediakan pada mikroprosesor virtual ini, dapat digunakan jika dituliskan secara manual dalam bentuk machine code langsung. Maka untuk membantu memudahkan belajar, instruksi-instruksi machine code cukup dituliskan dalam file teks (ASCII), misalnya menggunakan Notepad. Setiap instruksi dituliskan dalam satu baris berupa angka numerik desimal. Sehingga jika ada dua puluh instruksi maka ada dua puluh baris numerik decimal, lihat Gambar 2 .

Mengalihkan ide instruksi program, biasanya dalam bentuk pseudocode, ke dalam machine code membutuhkan upaya ekstra bila dilakukan secara manual. Sebuah kakas (tool) yaitu compiler telah dibuat yang dikembangkan menggunakan JavaFX, sehingga pengguna dapat menggunakan komputer virtual ini, dan menuliskan program dalam gaya penulisan pseudocode. Sebagai catatan, pada versi compiler yang ada saat ini, ada sebagian fasilitas operasi yang tersedia pada mikroprosesor belum dapat dimanfaatkan. Jika dikehendaki, maka terpaksa harus menuliskan dalam machine code langsung.

\section{PEMBAHASAN}

Mikroprosesor virtual yang dirancang dan diimplementasi merupakan mikroprosesor 32 bits, dilengkapi sejumlah register, menyediakan 16 buah register sebagai general purpose registers, register untuk stack, program counter, dan register untuk menangani multi program yang berada di memori. Penamaan 16 buah general purpose registers yaitu r0 hingga r15. Setiap register berukuran 32 bits.

Setiap instruksi berukuran sama yaitu 32 bits. Dari 32 bits tersebut dibagi ke dalam sejumlah fields, dan salah satunya adalah opcode sepanjang 8 bits, berada pada lokasi bit 24 hingga 31. Untuk instruksi yang termasuk operasi register, maka dari 32 bits disusun menjadi 5 fields, dan salah satunya dalah opcode, dan tiga fields lainnya adalah identitas registerregister yang digunakan, dan satu field lainnya untuk sementara tidak digunakan. Instruksi kategori operasi register di antaranya adalah operasi penambahan (ADD), pengurangan (SUB), perkalian (MUL). Setiap field register menggunakan 4 bits. Pada instruksi yang melibatkan akses ke dan dari memori, dari 32 bits dibagi menjadi 4 fields, dan satu di antaranya adalah opcode. Dua fields digunakan untuk identitas register, dan satu field digunakan untuk alamat atau immediate data. Beberapa instruksi melibatkan memori di antaranya adalah MOV, MOVB, MOVW, dan masih ada lainnya.

Berikut ini arsitektur dari komputer virtual, lihat Gambar 1. Komputer virtual adalah yang berada di dalam segiempat merah. Komputer virtual berjalan di atas komputer riil, tidak terkoneksi akses langsung ke sumber daya perangkat komputer sesungguhnya. Komputer virtual pada dasarnya adalah sebuah program aplikasi, seperti layaknya program-program aplikasi lainnya yang berajalan di atas host computer. Lapisan terbawah adalah sistem komputer virtual, terdiri dari mikroprosesor virtual, dan memori virtual. Lapisan di atasnya, adalah 
program aplikasi $(\sqrt{ })$ yang sudah dalam machine code, yang dituliskan dalam file teks (ASCII), dan dapat dieksekusi oleh komputer virtual. Atau alternatif lain memanfaatkan compiler yang mengalihkan pseudocode ke dalam machine code.

Berikut adalah beberapa instruksi yang difasilitasi dan dapat dikerjakan oleh mikroprosesor virtual, lihat Tabel 1.
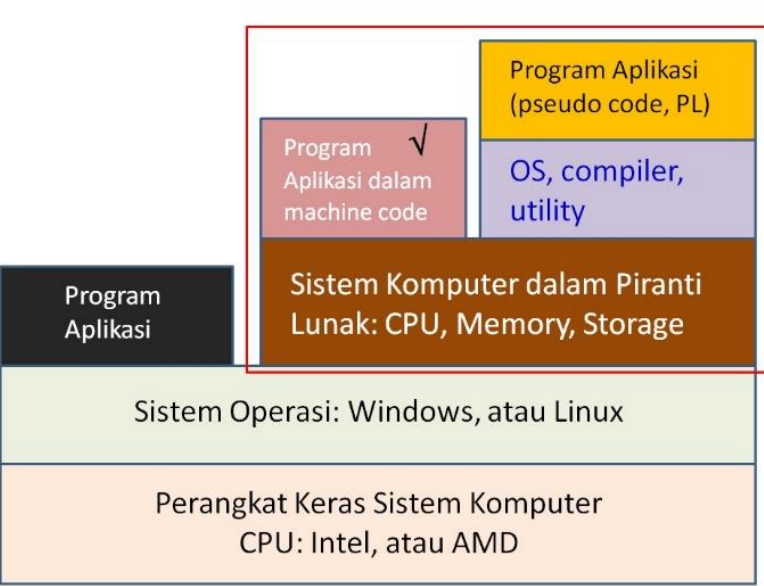

Gambar 1. Arsitektur Komputer Virtual

Tabel 1. Beberapa instuksi yang ada pada mikroprosesor virtual

\begin{tabular}{|c|c|c|c|}
\hline No & Jenis Heuristik & Fungsi & OpCode \\
\hline 1 & ADD & Penjumlahan register & 0x0 \\
\hline 2 & ADDI & Penjumlahan melibatkan immediate data & 0x01 \\
\hline 3 & HALT & Penghentian eksekusi instruksi & 0x7F \\
\hline 4 & CALL & Pemanggilan module & 0x22 \\
\hline 5 & RET & Kembali dari module & 0x23 \\
\hline 6 & MOV & Transfer data antar memori dan memori & 0x04 \\
\hline 7 & JMP & Unconditional jump & $0 \times 15$ \\
\hline 8 & JE & Conditional jump if equal & 0x17 \\
\hline 9 & JLT & Conditional jump if less than & 0x19 \\
\hline
\end{tabular}

Berikut ini sebuah contoh pseudocode yang dialihkan ke assembly code, dan machine code, lihat Gambar 2. Pseudocode program, lihat Gambar 2-a, yaitu menjumlahkan angka 1 hingga 10, semua data disimpan di register (yaitu r1 dan r2), dan hasilnya disimpan di register r2. Gambar 2-b, merupakan assembly language dari pseudocode kolom pertama. Dan, pada Gambar 2-c merupakan machine code dalam bentuk angka numerik desimal, sedangan angka pada tanda kurung siku adalah alamat memori di mana instruksi-instruksi tersebut akan ditempatkan di memori (Gambar 2-c).

$$
\begin{aligned}
& \mathrm{R} 1=0 \\
& \mathrm{r} 2=10 ; \\
& \begin{array}{r}
\text { While }(\mathrm{r} 1<10) \\
\mathrm{r} 2=\mathrm{r} 2+\mathrm{r} 1 \\
\mathrm{r} 1=\mathrm{r} 1+1
\end{array}
\end{aligned}
$$

Endwhile

End program movi r1, 0

movi r2, 10

movi $\mathrm{r} 3,10$

ulang: je r1, r3, endprogram

jgt r1, r3, endprogram

add $\mathrm{r} 2, \mathrm{r} 2$, r1

addi $\mathrm{r} 1, \mathrm{r} 1,1$

jmp ulang

endprogram: halt
[00] 51380224
[04] 52428810
[08] 53477386
[12] 387121184
[16] 437452832
[20] 2232320
[24] 17891329
[28] 352321548
[32] 2130706432
(a) pseudocode
(b) assembly code
(c) machine code

Gambar 2. Konversi pseudocode ke machine code 
Berikut ini adalah contoh compiler yang juga menampilkan kode program yang menampilkan sejumlah status informasi, lihat Gambar 3. Compiler ini menyajikan status eksekusi instruksi dari program yang sedang dieksekusi oleh computer virtual. Pada kolom paling kiri ditampilkan assembly code dari program yang telah terkompilasi. Kolom berikutnya ditunjukkan variabel-variabel yang digunakan dalam program yang dituliskan dalam pseudocode. Baris di bawahnya adalah data memori virtual, code program ditempatkan mulai pada alamat 0 (0x0000). Kolom paling kanan, menampilkan status register-register yang dimiliki oleh prosesor virtual.

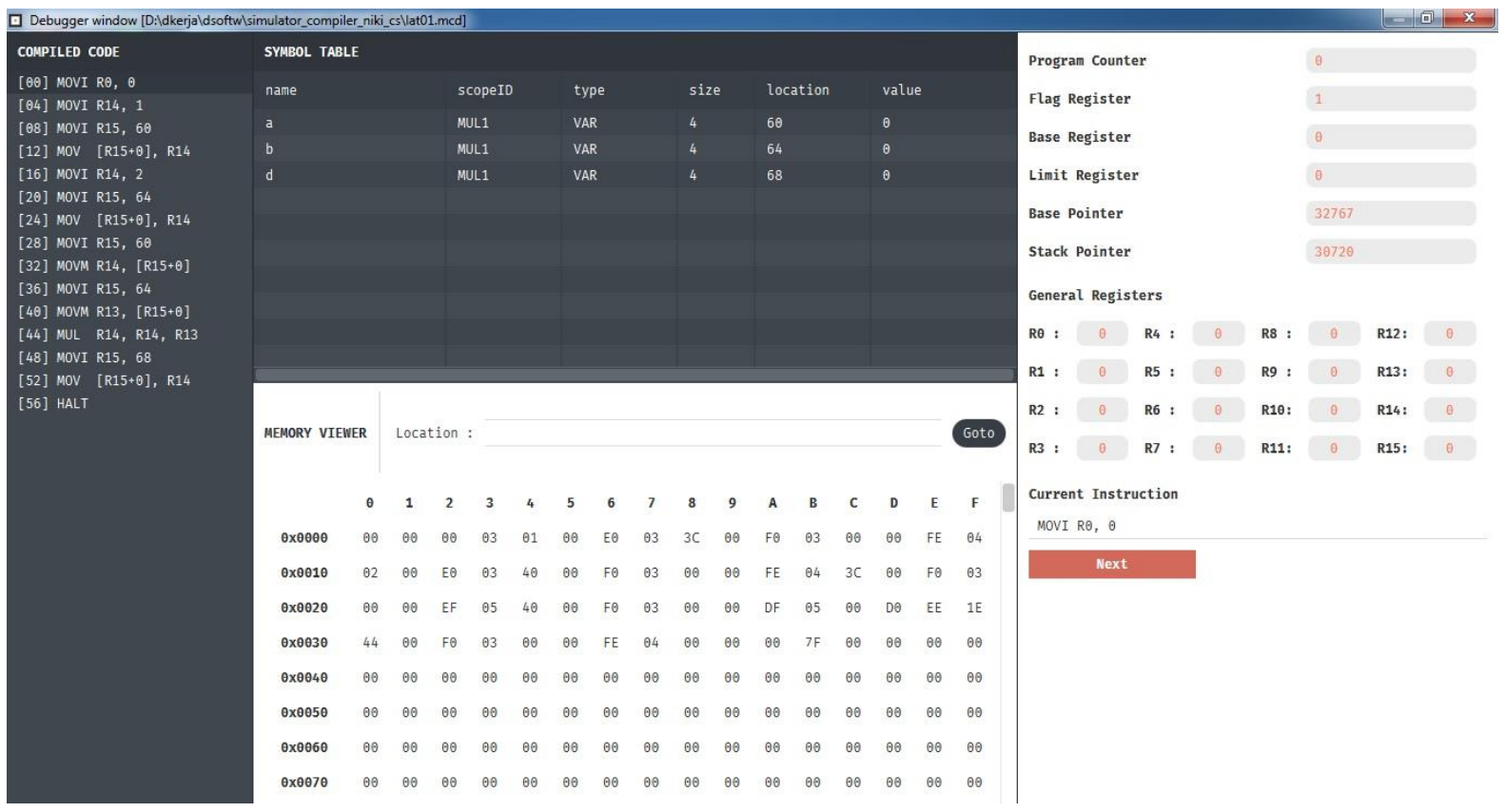

Gambar 3. Compiler dan status memori serta register dari program yang dieksekusi

\section{KESIMPULAN}

1. Mikroprosesor virtual berhasil dibuat berdasarkan rancangan arsitektur instruction set yang dibuat, merupakan mikroprosesor integer.

2. Sistem komputer virtual yang tersusun dari mikroprosesor virtual, dan memori virtual, dapat dibentuk, dan mampu mengeksekusi program yang ditulis dalam bahasa mesin berdasarkan mikroprosesor virtual tersebut.

3. Mikroprosesor virtual yang dibuat menyediakan sejumlah instruksi dasar yang diperlukan dalam pemrograman, yaitu operasi dasar aritmatika, assignment data ke lokasi memori (variable) ataupun ke register, serta antar register, unconditional dan conditional jump, operasi dasar stack, dan call module.

4. Sistem komputer virtual dapat menampung dua dua atau lebih program, meskipun eksekusinya masih dilakukan secara sekuensial.
5. Menggunakan sistem komputer virtual ini memungkinkan kita dapat memelajari untuk memahami konversi instruksi (code) assembly ke kode mesin (machine code).

6. Dapat digunakan untuk mendukung mata kuliah Sistem Operasi, dan atau mata kuliah Organisasi dan Arsitektur Komputer.

\section{DAFTAR PUSTAKA}

[1]. David A. Patterson, John L. Hennessy. Computer Organization and Design, The Hardwarel Software Interface. Morgan Kaufmann, Fourth Edition, 2012.

[2]. Intel. Intel 64 and IA-32 Architectures Software Developer's Manual, Volume 1: Basic Architecture. Intel Corporation 2008.

[3]. Intel. Intel 64 and IA-32 Architectures Software Developer's Manual, Volume 2A: Instruction Set Reference, A-M. Intel Corporation 2008. 